\title{
Protest Cycles and Political Process: American Peace Movements in the Nuclear Age
}

\author{
DAVID S. MEYER, UNIVERSITY OF MICHIGAN
}

\begin{abstract}
Since the dawn of the nuclear age small groups of activists have consistently protested both the content of United States national security policy, and the process by which it is made. Only occasionally, however, has concern about nuclear weapons spread beyond these relatively marginal groups, generated substantial public support, and reached mainstream political institutions. In this paper, I use histories of peace protest and analyses of the inside of these social movements and theoretical work on protest cycles to explain cycles of movement engagement and quiescence in terms of their relation to external political context, or the "structure of political opportunity." I begin with a brief review of the relevant literature on the origins of movements, noting parallels in the study of interest groups. Building on recent literature on political opportunity structure, I suggest a theoretical framework for understanding the lifecycle of a social movement that emphasizes the interaction between activist choices and political context, proposing a six-stage process through which challenging movements develop. Using this theoretical framework 1 examine the four cases of relatively broad antinuclear weapons mobilization in postwar America. I conclude with a discussion of movement cycles and their relation to political alignment, public policy, and institutional politics.
\end{abstract}

Helen Caldicott (1984: 13) reports that reading Nevil Shute's post-holocaust novel, On the Beach, awakened in her a concern about nuclear weapons and a passion for political action that animated her personal and political activity for the following decades. While Dr. Caldicott's efforts to press for nuclear

NOTE: I presented an earlier version of this paper at the annual meeting of the American Political Science Association, August 31, 1991, Washington, DC. For helpful comments on earlier drafts, I want to thank Jim Ennis, John Garofano, Doug Imig, Paul Joseph, Richard Kendrick, Richard Lachmann, Laura Reed, Tom Rochon, Mary Ann Steger, the members of the Boston College Media Research Action Project, and three anonymous reviewers. 
disarmament and arms control have been tireless, her audiences have been much less so. Activists throughout much of the world shared Caldicott's concerns about the dangers of nuclear war in the early 1960s. Just a few years later, however, media attention shifted to other issues, antinuclear organizations turned their efforts elsewhere, and nuclear war was a low priority on most activist agendas. Mass concern returned in the early 1980s when Caldicott was among the most visible leaders in the nuclear freeze campaign, speaking to large audiences in a wide variety of venues. Buoyed by the support of a large popular movement, which included the President's daughter, Caldicott even won a private meeting with President Reagan in the Oval Office. ${ }^{1}$ Just a few years later, however, Caldicott was dispirited at the movement's apparent demise; the organizations that had carried the movement were in financial and/or organizational crises, or moving on to other issues. This despite the fact that both superpowers still possessed some tens of thousands of nuclear weapons-easily capable of destroying the world-and the problems of nuclear proliferation had increased. This paper is concerned less with why Caldicott and a number of other dedicated activists have been able to maintain their commitments and activity, than with why the movements they participated in have fluctuated so dramatically.

Since the dawn of the nuclear age small groups of activists have consistently protested both the content of United States national security policy, and the process by which it is made. Only occasionally, however, has concern about nuclear weapons spread beyond these relatively marginal groups, generated substantial public support, and reached mainstream political institutions. Historians and analysts of specific campaigns have been able to identify the proximate causes of the rise and decline of particular movements, noting both the political context and activist decisions, but rarely do they attempt to discern more general explanations for the phenomenon of social movement cycles. More recently, a few analysts have recognized and commented on the sporadic nature of peace movement engagement (Boyer 1985; Kleidman 1993; Mushaben 1985; Wittner 1988), but they have been more concerned with claiming cumulative successes or avoiding what they see as recurrent activist mistakes than in explaining the causes of cyclicity. In this paper, I build on the histories of peace protest and analyses of the inside of these social movements and theoretical work on protest cycles to explain cycles of movement engagement and quiescence in terms of their relation to external political context.

1 Accounts of the meeting differ on details (Caldicott 1984: 26-32; Kelley 1991: 413-14; Reagan 1990), but agree it disappointed everyone involved. 
I begin with a brief review of the relevant literature on the origins of movements, noting parallels in the study of interest groups. Building on the concept of political opportunity structure, I suggest a theoretical framework for understanding movement cycles that emphasizes the interaction between activist choices and political context. I propose a six-stage development process for movements that recognizes the continuity between extra-institutional protest and institutional politics. Using this framework I examine the four cases of relatively broad antinuclear weapons mobilization in postwar America. I conclude with a discussion of movement cycles and their relation to public policy and institutional politics.

\section{On Political Context and the Emergence of Protest Movements}

The question of why movements emerge has rightly occupied much scholarly attention in both political science and sociology. The first wave of "collective behavior" analysis in sociology (Smelser 1963) viewed movements as a product of societal dysfunction, specifically the incapacity of society to integrate its citizenry (e.g., Kornhauser 1959). Movements represented a failure of social or political institutions. The basic tenets of collective behavior approaches did not stand up to empirical verification; they were also subject to political challenge as they effectively "explained away" the real political grievances challenging movements expressed. Scholars studying the social movements of the 1960s developed a "resource mobilization" perspective (Lipsky 1970; McCarthy and Zald 1977; Oberschall 1973) that emphasized not social failure but activist success. In this paradigm movements represent the purposive application of resources to a social problem; essentially, protest as politics by other means. Initially resource mobilization analysts were less concerned with the political environment in which movements operated than in the tactics and strategies organizers devised to overcome the "free rider" problem, that is the "rational" tendency of citizens not to pursue collective goods through political action (Olson 1965).

In political science, analysis of interest group origins developed in a similar manner, albeit with important normative differences. Truman (1951) argued that interest groups reflected and arose from "disturbances" produced by new constituencies or problems. In contrast to the collective behavior school, however, Truman and other pluralist analysts (e.g., Dahl 1963) viewed the development of groups as a social good, reflecting a healthy democratic polity. Critics quickly noted, however, that all disturbances were not equally likely to create interest groups, that the political system advantaged certain constituencies and problems (Bacharach and Baratz 1970; Schattschneider 1960), and that elite support was critical to a group's emergence (Walker 1983, 1991), especially for groups that pursued various visions of the public 
interest (Berry 1977; McFarland 1984). Analysts focused on the "issue entrepreneur" who, by developing "exchange relationships" with constituents, mobilized support and sustained a group (Salisbury 1969).

In both disciplines, students of interest groups and social movements looked first at the larger society to explain and understand disruptive politics, then shifted their analyses to micromobilization problems. Clearly, we need to look at both activist efforts and political context to explain protest challenges. A "free rider" is likely to re-evaluate the costs and benefits of participation as political circumstances change (Meyer and Imig 1993). Thus activists against nuclear power drew larger crowds at demonstrations shortly after the reactor accident at Three Mile Island, environmentalists found it easier to raise money when the Secretary of Interior advocated opening national parks for development, and abortion rights activists found mass media more attentive when the Supreme Court seemed less likely to protect these rights (Schlozman and Tierney 1986). Similarly, funders are more likely to turn to interest groups or social movements when they believe other means of influence on critical issues are foreclosed, and the clever issue entrepreneur is most likely to succeed when the issues she addresses are those of broad public concern.

Most recently, students of both interest groups and social movements have recognized the essentially political character of extra-institutional dissent, and its relationship to institutional political activity. In a study of challenging groups in America before World War II, Gamson (1990) found that the structure of United States political institutions advantaged certain constituencies and strategies of influence. Jenkins and Perrow (1977) identified the critical role elite supporters played in aiding and amplifying recurrent farmworker campaigns. Freeman (1975) emphasized the important role that public policy played in the tactics women's rights activists chose; similarly Hansen (1985) looked at the policy context to evaluate farmers' success and failure in mobilizing challenging movements. In his studies of the civil rights movement, McAdam (1982) advanced a political process perspective on social movements that integrated close analysis of activist choices with a larger view of both public policy and the political system. The essential point underlying all of this work, as McAdam emphasized, is that the opportunities for protest vary between policy areas and over time, and that they are closely tied to institutional politics.

\section{Polmital Opportunity: Structure and Space}

"Political opportunity structure" (POS) promises the most productive way to integrate analytically the process of political action with the social context in which it takes place. Primarily used as a theoretical tool in cross-sectional comparisons of protest in cities (Eisinger 1973), states (Amenta and Zylan 
1991), or nations (Kitschelt 1986; Tilly 1978), POS refers to the institutional and political factors that shape social movement options. To date, analysts have described a broad range of aspects of political opportunity as structure. Summarizing this work, Tarrow (1988: 430) identifies five interdependent variables comprising POS: the degree of openness in a political system; the stability of political alignments; the relationships between challengers, and between challenging groups and supporters; the nature of elite cohesiveness and tolerance to protest; and the patterns of intermediation between state and society.

Building on Tarrow's work, we can specify POS more clearly so that concepts can be applied across time, different movements, and states. We can begin by making a rough distinction between relatively stable aspects of opportunity, particularly regarding political culture and institutional arrangements, and more dynamic aspects of opportunity, which involve partisan alignment and elite allegiance. Meyer (1990: 8) describes these more fluid elements of opportunity as "political space," or "the opportunities for legitimate mobilization not monopolized by established linkage mechanisms." Even in the context of stable institutions, opportunities are influenced by changing positions of elites, parties, and/or interest groups (Byrne 1991), and also by the changing boundaries of legitimacy in discourse (cf. Gamson 1988). The fluid aspects of opportunity are critical in explaining social movement cycles; political opportunity stuctures did not change appreciably in the past four decades. The United States maintains generally the same electoral structure, dominated by two parties, the same weak policy implementation structures, and the same single-member district system of representation. Nonetheless, the success and issues of challenging movements have changed dramatically-as has the relative positioning of actors within the structure of political opportunity.

Political space exists when there is a disjuncture between popular concerns and public policy that established institutions, particularly parties or interest groups, are not addressing. This disjuncture can be the result of changes in opinion, policy, or political alignments. Political opportunity, of course, is not synonymous with protest, nor does it cause protest. Rather, changes in opportunity alter the prospects for activist challengers to reach a broader audience and potentially influence policy. States and related social and political institutions have a variety of possible responses to insurgent movements, including ignoring them. When this is impossible, parties and governments may seek to suppress movements, coopt their concerns and language, and/or acquiesce to movement demands. Most significantly, established institutions and actors reclaim their political hegemony, crowding insurgent movements out of the political space they once occupied. This is the 
basis for a cyclic pattern of social movement challenges, as concerns or constituencies that may occasionally emerge in extra-institutional protest are reintegrated with the polity and dissidents adopt less disruptive means of political participation.

Recognition of cycles of movement challenges and quiescence is not new. Oddly, however, theorists have tended to attribute variations in dissident mobilization to essential constants: for example, the inevitability of disappointment in human nature (Hirschman 1982), the intractability of social problems (Downs 1972), or macrohistorical patterns in history (Schlesinger 1986). Tarrow (1989) offers a more promising approach, explaining protest cycles by looking at varying political circumstances, or shifts in political opportunity. As Klandermans (1991: 14) argues, "A cycle of protest is a fundamentally political process; political opportunities play a crucial role in the development and decline of such cycles."

Most theories of political opportunity are global in nature, emphasizing opportunity writ large for all sorts of social movements (e.g., Brand 1990; Goldstone 1980; Tarrow 1991), times when states are most receptive or vulnerable to insurgent challenges; they make few distinctions regarding the causes or constituencies challengers embrace. Tarrow's (1989) cycles of protest are defined by a broad range of actors engaging in unconventional action in pursuit of a wide range of goals. Clearly, however, under certain circumstances one set of issues will become more salient than another. The external political environment also shapes decisions elite actors make about whether to sponsor, tolerate, or repress protest activity (Walker 1991), and whether to pursue their own goals through institutional or extra-institutional activity. Individuals choose to exercise "voice" alone-by participating in conventional politics, or in conjunction with institutional "exit" - by abandoning or supplementing conventional political activity. As Hirschman (1970: 104-105) explains, " . . the alternative is now not so much between voice and exit as between voice from within and voice from without (after exit). The exit decision then hinges on a totally new question: At what point is one more effective ... fighting mistaken policies from without than continuing the attempt to change policies from within?" People make this decision by evaluating the relative prospects for influence each strategy promises at a given time.

Policy analysts, who look at specific issue areas and opportunities within them, help us look at variations in opportunity. Kingdon (1984), examining the ascendence of particular issues within government, terms the opportunity for major policy innovation or reform an "open window." Windows open, he suggests, in response to three distinct streams, politics, policy, and problems. When they do, "issue entrepreneurs" may win access to political decisionmakers and even influence within the arenas of power. Political organizers, 
sponsors, and occasional activists choose causes and conduct in response to their judgment about how open various windows are. Public policy and political alignment make certain issues most attractive or urgent to organizers and more vulnerable to outside influence. It is not then surprising that Americans concerned with peace and social justice might work for a nuclear test ban in 1963, civil rights in 1964, and to stop military escalation in Vietnam in 1965. Government responses, such as negotiating a test ban treaty in 1963 and passing a Civil Rights Act in 1964, make extra-institutional politics appear less necessary, as institutional actors ostensibly pursued similar goals with some success. As institutional actors claim some portion of activist goals and rhetoric, challengers must cope with less available political space. Cycles of protest, unlike waves or cyclic patterns in the physical sciences, are bounded by the contingent nature of movement claims and state responses. As a result, the concept is more useful in analyzing cyclic patterns in movement challenges than in predicting the emergence, development, or outcomes of challenging campaigns.

\section{Opportunity and the Efficiency Principle}

People naturally and rationally seek the most direct lines of influence they believe possible (Downs 1957). One's political choices are rightly affected by one's proximity to the locus of decision making, available political resources, the magnitude of the changes sought, as well as the responsiveness of those in power to both dissenters and their ideas. An elected official, for example, has greater access to policymaking power than a voter. Proximity to power, however, brings with it restrictions on both tactics and ideas. Comprehensive reforms or criticisms rarely come from above; rather, those close to power generally manage marginal increments of reform rather than wholesale changes, and then usually in response to pressure for greater changes from below. Political tactics also change in relation to an actor's social and political location. Neither Robert McNamara nor Richard Perle, for example, recent critics of United States national security policy, is likely to lie across railroad tracks or throw rocks to promote his policy preferences; their ideas may not be so different from current policy that such conduct appears warranted; more significantly, each man has more direct and potentially efficacious routes to influence. Much further from the center of the policy process, poor people dependent upon government support are unlikely to exercise influence except by extreme political methods (Piven and Cloward 1979).

We can think about this principle of efficient choice as hierarchical. Everyone might prefer to exercise influence by sneaking through a policy window to a president's office. If this option appears foreclosed, however, an "issue entrepreneur" is likely to seek influence elsewhere, either in the bureaucracy, 
Congress, or in many policy arenas at lower levels of government; the judicial system, the media, and the mass public generally provide less direct routes to influence. People pick the route they believe most likely to be effective after surveying their political resources and opportunities. Rarely does one protest outside the White House when one believes that he can effect meaningful influence within. ${ }^{2}$ Thus there is a process of seeking an open window at the highest possible level. Lower levels of government and society are generally permeable to citizen access, but they are also distant from policy influence. (As a result, the incentive to participate at lowest levels also diminishes.) Even though the decision about whether and how to participate is rational, the information one considers in making it is socially constructed. The urgency of an issue, the viability of various policy alternatives, the range of available froms of collective action (Tilly 1978), and the likely efficacy of alternative tactics are all subject to manipulation by government, activists, and other interested parties (Edelman 1971; Gamson 1988; Ryan 1991).

The American polity was designed as a self-righting and stable system that allows relatively easy access to a wide variety of groups and individuals, but strictly limits the influence any group can have on policy. Historically, successful challenging groups have emphasized entrance to and legitimation within the political system, rather than either substantive or structural changes (Gamson 1990). As a result, the process of social mobilization has cyclical elements, as extra-institutional mobilization gives way to organization-building and institutionalization. Established organizations routinize their behavior to ensure organizational maintenance and stability (Walker 1991: 15), and become a component of the political opportunity structure new challengers face. Meyer and Imig (1993) offer a schematic view of the process:

1. Policy Problem: change in objective conditions, or perceptions of conditions.

2. Elite schism: divisions among elites about definitions of problems and potential solutions.

3. Media attention: recognizing problem, framing potential solutions, defining legitimate players.

4. Dissident Activism: projection of policy alternatives

5. Elite response: alliance building; redefinition of challenging claims.

6. Institutional Accommodation: management of problem; fragmentation of dissident coalition.

2 Linus Pauling provides a notable exception to illustrate the general rule. In 1962, protesting the United States' decision to resume nuclear testing, Pauling picketed the White House on April 28, then attended a dinner for Nobel laureates inside the next day (Seaborg: 150-51). 
This model locates the origin of challenging social movements in the policy process, assuming that protest expresses some kind of collective rationality, and that what happens on the edge of political institutions is closely related to what occurs within. Clearly all changes in policy or governmental process do not lead to mass social protest; the extent of movement activism depends upon the state's political management of elite dissent, and the strategic and tactical choices dissidents make. At every stage of the sequence, further development may be preempted by state action and/or activist choices. Further, it is important to recognize that these processes are not completely distinct and sequential; rather, there is an ongoing interactive process of definition among all the players (Solop 1991). Nonetheless, the model provides a framework for organizing analyses and comparing dissident social movements over time.

\section{Cycles of Peace Protest in America}

Protest movements are comprised of diverse efforts, potentially including institutional politics, extra-institutional protest, political violence, public education programs, and cultural activities. There are very visible venues, such as the floor of the House of Representatives or the Nevada atomic testing site, and far less visible ones, including local governments and activist living rooms. Nonetheless, scholars and activists share a broad consensus about the peaks and troughs of mobilization against nuclear weapons (DeBenedetti 1980; Kleidman 1993; Wittner 1984, 1988). Activists staged two broadbased mass movements against U.S. nuclear weapons policy, one running from 1955 to 1963 (the test ban campaign), the next emerging in the early 1980 s (the nuclear freeze movement). Two smaller challenges were comprised of elite-based campaigns with less extensive mass support and political visibility, one from 1945 to 1947 , in response to the immediate shock of the Hiroshima bomb, the other from 1968 to 1972, during the debate on antiballistic missile (ABM) deployment. The figures below provide a crude measure of movement challenges using the New York Times' monthly coverage of this broad range of opposition to the U.S. government's nuclear weapons policies.

Peace organizations survived throughout the postwar period, and before, but their number, resources, and success in mobilizing mass attention and mainstream support varied dramatically. It is, of course, possible that periods of mass attention reflected that activists at those times were particularly sophisticated or clever in crafting appeals and devising strategies. This is doubtful; the diversity of challenging groups, and the continued presence of many of the same leaders in both good times and bad, suggest that variations in activist tactics cannot explain movement cycles well. Further, the peace group sector as a whole has fluctuated in concert, with both radical and mod- 
erate groups flourishing and fading at roughly the same times (Wittner 1984). Nor has mass public opinion on nuclear weapons changed dramatically. Most Americans have historically been scared of both nuclear weapons and the Soviet Union (e.g., Graham 1989; Yankelovich and Doble 1984). Politicians, peace activists, and policymakers have played these fears off each other, and one fear or another has dominated at times (Miller 1985), but clearly it is not so much base mass opinion that changes, but rather the intensity of concern and policy preferences, and the strategic political choices dissidents make. Taken together, this is the mobilization context, or the political space available to movements. By looking at cyclic challenges in the four campaigns, we can see the changing nature of political opportunity, that is, shifts in available political space.

\section{The Scientists' Campaign for International Control $^{3}$}

The policy problem that spurred the first antinuclear movement was the introduction of nuclear weapons into the calculus of United States foreign and military policy, which virtually mandated a radical departure from previous policies. Importantly, even before the war, and among those few people actually aware of the bomb's existence, there was no consensus about either the use of atomic weapons or their eventual role in foreign policy. An elite schism thus preceded even public knowledge of the bomb and the attendant political decisions it mandated. In 1944 Neils Bohr and a number of other scientists asked U.S. leaders to share information about the development of nuclear weapons with their allies in order to begin building a cooperative atomic weapons control regime to commence after the war. American officials were suspicious, dismissed the ideas, and placed Bohr under surveillance. Similarly, early in 1945 the Franck report calling for a demonstration of the bomb rather than its use against Japan was dismissed without much thought. The end of the war allowed debates that had been kept within a small circle of experts to reach the mass media and the general public, creating a policy problem as the elite policy debate was no longer contained by wartime consensus or political management.

Mass media attention to the devastating new weapon seen to have ended the war was understandably overwhelming. The horrific destruction at Hiroshima seemed to usher in an era of new possibility and urgency. Almost immediately after the news became public, newspapers, magazines, and movies grappled with the bomb. Norman Cousins' influential essay, "Modern Man is Obsolete," written just a week after the Nagasaki bomb, was in many ways

3 This section draws on Boyer 1985; Bundy 1988; DeBenedetti 1980; Josephson 1988; McCrae and Markle 1989; Smith 1965; Wittner 1984. 
a characteristic response. The bomb raised existential questions, Cousins wrote, "Is war in the nature of man?" For Cousins (1945: 8), nuclear weapons represented a new problem for which there was only one solution: "In the absence of world control as part of world government, it [the atomic bomb] will create universal fear and suspicion." Cousins, along with numerous other writers, called for moral consideration and unspecified political action. Thus while the media fed public curiosity in the bomb, it attached no clear solutions to the problems it identified.

EFigure 1

New York Times Coverage of Opposition to US National Security Policies, BY MONTH, 1945-51

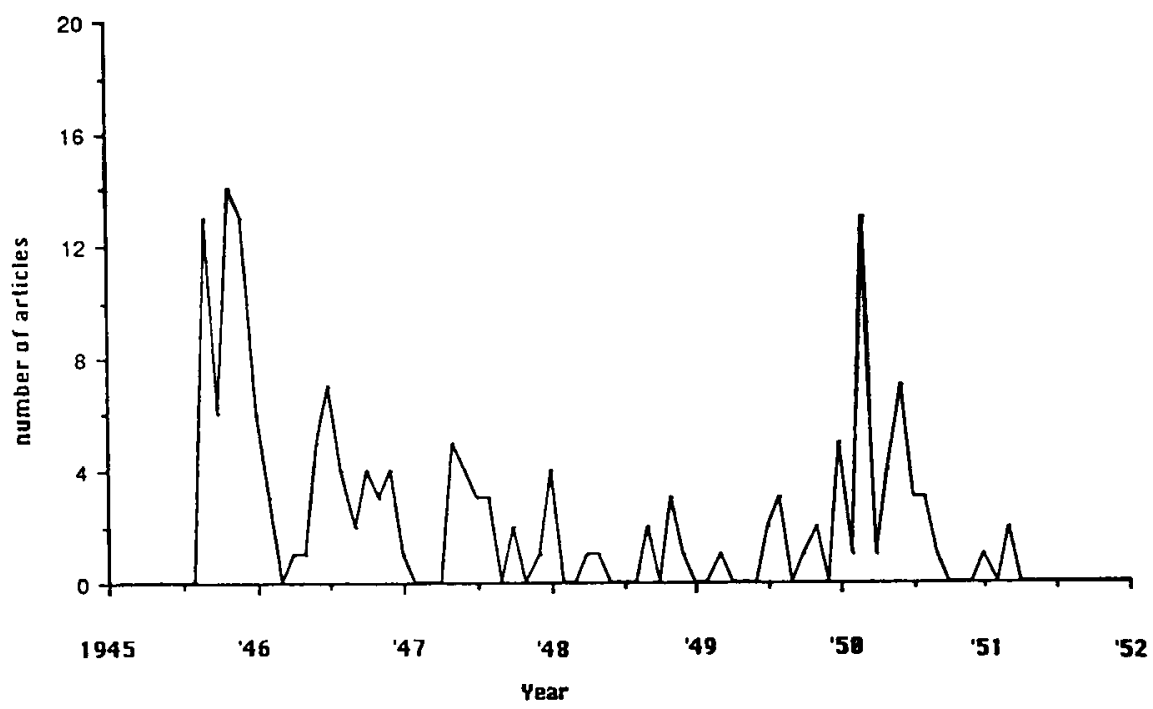

Source: New York Times Inder

Atomic weapons came to the head of the agenda in both academia and mass culture. Magazines and academic journals published special issues, academic and cultural organizations sponsored symposia, and politicians inside and outside of government called for mass education on nuclear weapons. Boyer (1985: 32) writes there were two essential components to the American response to atomic weapons: fear, and an "unfocused conviction that an urgent and decisive response was essential," although there was no clarity on what this response might be. The most frequently articulated alternative policies were those Cousins proposed: international control of nuclear weapons, and world government. Several local groups of scientists formed by the end of 
1945 , all concerned with public education on nuclear weapons, most notably through the new Bulletin of the Atomic Scientists, and supportive of international control. Non-scientists-including future president Ronald Reagan (Cannon 1991: 62, 292)-joined the United World Federalists, also formed shortly after the war, pressing for international cooperation. Importantly, none of these groups provided blueprints for government policy or citizen action. As a result, dissident action was confined to public discussions of generally vague ideals, and not political activity of any kind.

Elite responses, inside and outside of government, continued the debate begun before Hiroshima. Within government, Secretary of State Byrnes commissioned a high-profile commission to consider the new issues of the nuclear age. The Acheson-Lilienthal "Report on International Control of Atomic Energy" called for the United Nations to establish an international atomic control regime. The administration divided on the issue, however, and President Truman's appointment of Bernard Baruch as special ambassador on international atomic weapons control, by all accounts, doomed the plan to failure. Negotiations with the Soviet Union in the UN stalled over Baruch's insistence on swift and sure punishment for treaty violations, a system that would effectively nullify the Soviets' UN veto. By early 1948 the UN proposal was dead, and division within the administration prevented bilateral agreements with the Soviet Union. Although nuclear issues were discussed in great detail in all sorts of public venues, the focus was generally on existential shock rather than political alternatives.

The heated policy debate never reached the general public. For most people the war's end meant demilitarization and remobilization of the American economy (Huntington 1961: 35). Domestic affairs dominated government and public attention. Activist leaders demanded public attention and action, but failed to provide attractive or even potentially efficacious strategies for action. The most visible proposal for responding to the new nuclear threat was an ill-defined plan for the international control of nuclear weapons, sometimes expressed as a demand for world government. The Truman administration, Byrnes and Truman particularly, was skeptical of these plans, but it ostensibly pursued them in the UN. The "Baruch plan" coopted or preempted disarmament advocates. The Truman administration was able to manage the debate essentially by accepting the general concerns and language of advocates of international control, but attaching its own conditions. The government's institutional accomodation of partisans of restraint was to endorse the sentiment, but emphasize its impossibility. The administration, and indeed most of the public and many peace activists, blamed the failure of international control on Soviet intransigence. Truman responded to the growing threat he saw by developing a strong and permanent national security establishment, 
operating both abroad and in the United States, and securing a network of alliances to contain Soviet expansionism.

In response to developing Soviet policies - and the harsher and more critical domestic political environment- most activists perceived little altemative but to support United States policies. The road to disarmament and international cooperation led through the Soviet Union, a path foreclosed in foreign policy by Soviet action, and domestically by a new obsession with internal security. The administration worked to displace public fear of nuclear weapons to a more immediate fear of the Soviet Union, and framed international cooperation to include only Western allies. Media attention was massive, but essentially undirected. Both governmental and non-governmental elites substituted unilateralism for internationalism. Cord Meyer, Jr., first head of the World Federalists, and author of One World or None, joined the CIA to pursue a new internationalist vision. Many supporters of international control also supported the Korean war, imagining a new era of international cooperation springing from the multilateral military effort. Fear of nuclear weapons was outstripped by fear of the Soviet Union, and ameliorated with optimism about the promise of atomic energy (Boyer 1985). Antinuclear activism disappeared from the public debate as a new Cold War consensus emerged, a consensus so broad that it was fairly easy to marginalize or repress those who might question it. Mass concern never translated into political action. Absent substantial mass dissident action, the government could manage the conflicts about nuclear weaponry on its own terms, institutionalizing dissent by coopting public concerns about common security in the service of unilateralism.

\section{The Test Ban Campaign ${ }^{4}$}

The test ban campaign resulted from a coincidence of a new provocation, demonstrable evidence of the dangers of atmospheric testing, and enhanced political opportunity. The end of the Korean War and the censure of Senator Joseph McCarthy opened space for political debate inside and outside government. Lessened fear of repression allowed dissidents to question government policy openly and to propose new alternatives. Concern about nuclear weapons generally, and atomic testing specifically, animated three waves of peace activism, punctuated by two presidential elections. Each wave of activism was greater than the one preceding, as the 1956 and 1960 elections failed to resolve public fears of radioactive fallout quickly or easily. Public recognition of the dangers of testing created the relevant policy problem. The March 1954 BRAVO tests in the Bikini Islands catapulted nuclear weapons and the

4 This section draws on Bundy 1988; DeBenedetti 1980; Divine 1978; Katz 1986; Kleidman 1993; Knopf 1991; Seaborg 1981; Wittner 1984; York 1987. 
를 2

New York Times Coverage of Opposition to US National Security Policies, BY MONTH, 1951-64

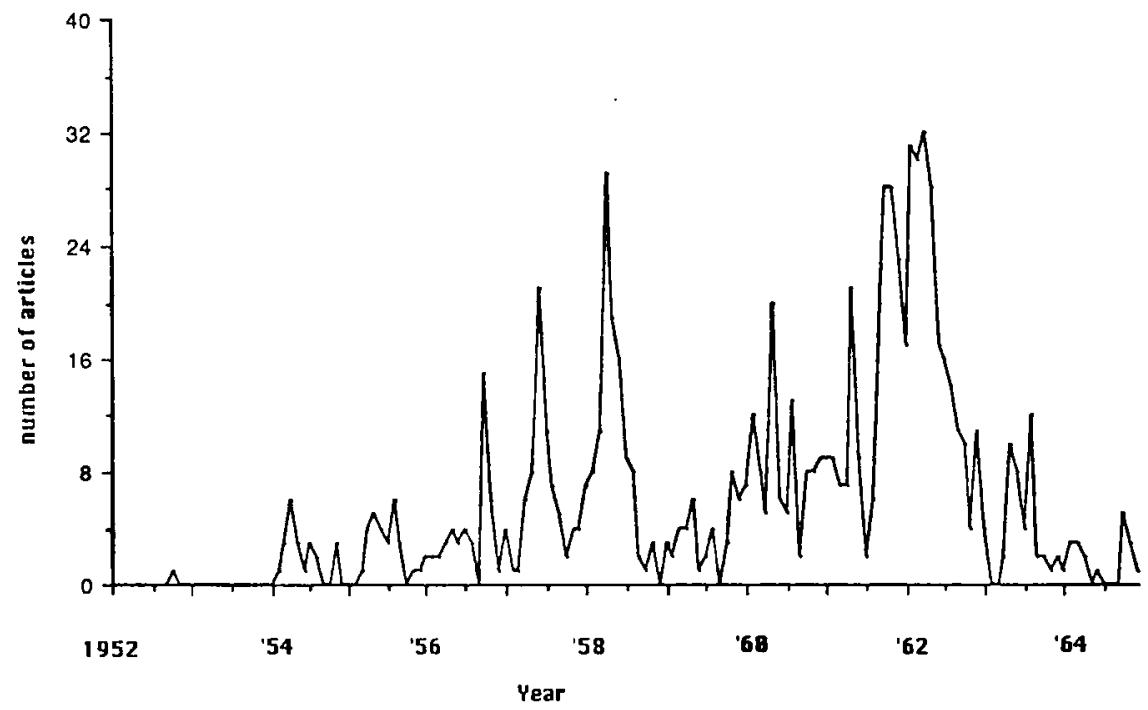

Source: New York Times Inder

arms race to mass public attention. Radioactive fallout from one test covered The Lucky Dragon, a Japanese tuna trawler, contaminating its crew and catch, and drawing international attention to the hazards of atomic testing.

An elite schism was visible almost immediately, as international allies, including Pope Pius XII, Jawaharal Nehru, the British Labour party, and the Japanese Diet appealed to United States to stop testing and negotiate a test ban. Media attention followed both reports on the testing and international criticism, as doctors and scientists debated the dangers of radioactive fallout in both specialized journals and mass market magazines. This spurred an almost immediate wave of dissident activism directed toward the demands of testing critics. International efforts were echoed and amplified at home; hundreds of letters arrived daily at the White House supporting a test ban.

The Eisenhower administration was divided on test ban proposals, and even on whether or not to release complete information on radioactive fallout from the recent tests. This division, and the administration's incapacity to respond to public concern effectively, allowed others to define the problem and possible solutions. Scientists were most notable in framing elite responses. In February 1955, physicist Ralph Lapp published detailed information on the BRAVO fallout in the Bulletin of the Atomic Scientists, nearly a week before the Atomic Energy Commission released its own report. Lapp's ability to 
scoop the government helped undermine public confidence in the Eisenhower administration. Shortly afterward, a group of international scientists issued the "Einstein-Russell Manifesto," calling for an end to both testing and the arms race. Test ban proponents approached the issue with a variety of concerns, some seeking simply to stop radioactive fallout, others to slow the technological arms race, while still others saw a test ban campaign as a way to build a broad movement for nuclear disarmament. Public debates among scientists and military experts raged about the necessity of continued testing, the dangers of fallout, and the reliability of non-intrusive means to detect testing.

The debates found a broad and interested audience. Public recognition of the dangers of nuclear fallout provided an opening for peace activists to lodge claims against the nuclear arms race and the United States' role in it. Fear of fallout, coupled with increased anxiety about US preparations for war with the Soviet Union, especially a large domestic civil defense campaign, provided a fertile base of support upon which activists could draw. The federal government's neglect of growing public concern opened political space for dissent, space first claimed by pacifist activists. On June 15, 1955, when New York City conducted its first annual air raid drill, several members of the Catholic Workers refused to take cover in a shelter, sitting on park benches and waving placards instead. Police arrested 29 people, and the trial judge set bail at $\$ 1500$, denouncing the protesters as "murderers" (Ellsberg 1983: 277-78).

Both the Republican administration and the Democratic opposition made efforts at institutional accomodation. Public pressure led Eisenhower to appoint Harold Stassen as a special adviser on disarmament. In 1956, as the Senate held hearings on testing, activists urged Democratic presidential candidate Adlai Stevenson to support a test ban. Against the advice of campaign staff, Stevenson made the issue a central point in his campaign. Eisenhower, personally ambivalent about a test ban, refused to discuss it publicly, arguing against politicizing national security matters. Shortly after winning reelection, however, he instructed his staff to explore possibilities for negotiated limits on testing more vigorously.

These efforts at accomodation failed visibly. Shortly after his appointment, Stassen announced that disarmament was impossible as a practical matter. Stevenson's defeat spurred further anti-testing activism, as it dashed hopes that meaningful reform could be achieved through the electoral process. Dissident activism reemerged in a wide variety of forms as test ban advocates sought other routes for influence, as two broad wings of a movement emerged. One called for international agreements coupled with unilateral restraint, and pressed its claims through public education efforts. Its adherents issued appeals, staged international conferences, including the first Pugwash 
meeting, organized rallies, and ran newspaper and television advertisements. SANE, the Committee for a Sane Nuclear Policy, founded in 1957, typified this liberal internationalist approach. Concurrently, several groups drawing from smaller left and pacifist bases of support launched a campaign of civil disobedience and direct action aimed at raising the political costs of continued testing. Activists again disrupted civil defense exercises in New York City, sitting on benches outside City Hall with signs such as "End War-the only defense against Atomic Weapons." Pacifist leader A. J. Muste organized a series of trespass campaigns on the Nevada test site (Robinson 1986).

Muste also helped raise money for a more dramatic trespass effort, pacifist Albert Bigelow's (1959) attempt to sail The Golden Rule into the Pacific test site in 1958. Stalled by repeated arrests, Bigelow and his crew did not get close to the test site, but inspired anthropologist Earle Reynolds in a similar effort with his ship, the Phoenix. In the United States media attention to these efforts was extensive, creating political space for a more moderate public education campaign. Dramatic direct action efforts expanded the boundaries of legitimate public discourse. Subsequently pacifist activists organized peace walks, sit-in demonstrations, and other civil disobedience efforts. Activists recognized the two wings of the movement working in concert would heighten the visibility and effectiveness of both. Many of SANE's founders simultaneously organized the Committee for Non-Violent Action to coordinate pacifist efforts.

As the movement grew, however, and particularly as it won attention (and the promise of political response) from the media and elected officials, it focused more narrowly on a test ban. By the middle of 1957, even Secretary of State John Foster Dulles was open to negotiating a test ban, largely because of what he described as the "propaganda drubbings" the United States was taking on the issue (Seaborg 1981: 10). Eisenhower and Khrushev presided over a testing moratorium from 1958-1960. The moratorium stalled dissent of all kinds, as the administration had seemingly made effective progress in resolving, or at least stilling, the policy problem of testing.

Activism would reemerge with the problem of nuclear testing. In the 1960 campaign both presidential candidates promised increased efforts to secure an arms control agreement on testing. Formal negotiations stalled however, and Eisenhower emphatically advised incoming President Kennedy about the need to resume testing. (This stands in contrast to his well-known farewell address warning of the dangers of the military-industrial complex.) Increased testing on both sides early in Kennedy's term spurred protest efforts and activism. The Cuban missile crisis underscored the urgency of managing the nuclear rivalry with the Soviet Union, and accentuated the administration's drive to establish an arms control regime. Kennedy used 
antinuclear activist Norman Cousins to open a back channel for negotiations with Khrushchev, securing an agreement to ban atmospheric testing. The government thus forged an effective alliance with elite leaders in the movement. The eventual agreement stopped the present danger of atmospheric testing; it also effectively ended the antinuclear movement.

"The limited test ban was more an environmental measure than arms control," said Spurgeon Keeny, who had served as a science adviser to President Kennedy. "It made the world safe for testing" (Herken 1987: 186). Nonetheless, the more institutional wing of the peace movement, led by SANE, actively lobbied the Senate to secure ratification, a ratification President Kennedy bought with a commitment to an accelerated underground testing program. The end of superpower atmospheric testing and the establishment of an ongoing arms control process also restored a new elite consensus, institutionalizing both arms control and a technological arms race. It effectively protected US nuclear policies from strong domestic criticism. The partial test ban, certainly much less than most activists called for, nonetheless limited activists' ability to press broader claims. Kennedy's institutional accomodation legitimated both control and modernization of nuclear weapons, and effectively institutionalized partisans of both positions.

\section{The ABM Debate 5}

Antiballistic missile systems continue to pose a difficult challenge for US policymakers, an unresolved policy generally managed successfully so that it does not become a public policy problem. The notion of developing an impermeable shield to secure Americans against nuclear attack has obvious political appeal. At the same time, the costs, technological limitations, and strategic implications of deploying an anti-missile system are strong disincentives. For years the United States had effectively avoided a decision by foregoing deployment of successive generations of ABMs while researching more capable follow-on systems. The Soviet deployment of the Galosh ABM system outside Moscow in 1966 provoked a policy debate within the Johnson administration, increasing the urgency of an $A B M$ decision. This forced decision window, amid a pre-existing elite schism, created both political and policy problems. Some civilian strategists, acknowledging the high cost and dubious military value of an $A B M$, urged Johnson to deploy a system anyway, emphasizing its symbolic importance. For Secretary of Defense McNamara, the decision not to deploy was easy on tecnical grounds, but difficult politically. Although he rejected development of a "heavy" system to defend against

5 This section draws from Bundy 1988; Herken 1987; Katz 1986; McNamara 1968;

Primack and von Hippel 1974; York 1987. 


\section{EFigure 3}

New York Times Coverage of Opposition to US National Security Policies, BY MONTH, 1964-76

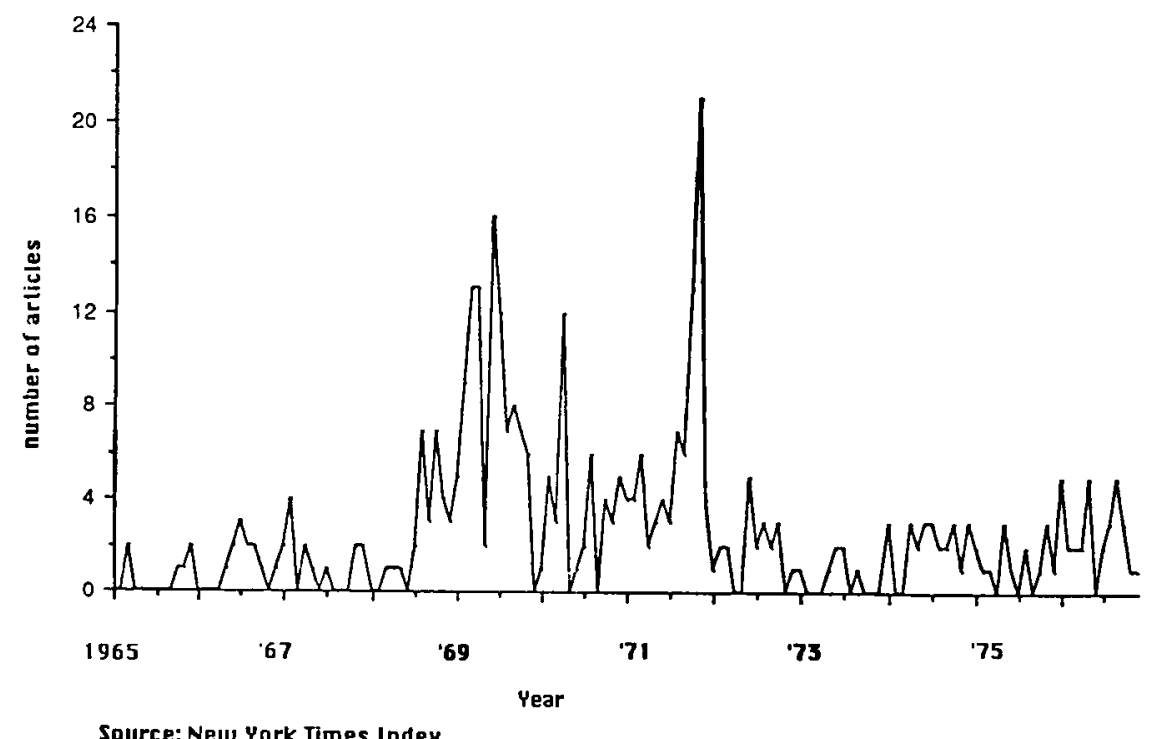

Soviet missiles, he proposed instead a "light" system, ostensibly to guard against China and other small nuclear forces (see McNamara 1968).

The Secretary's half-answer, clearly devised more as a political than a strategic move, satisfied no one. ABM supporters charged the Johnson administration with leaving America undefended. Scientific opponents of the ABM also addressed the issue aggressively and publicized their differences with the administration through articles in scientific journals and testimony before Congress. Media attention, albeit more modest than the test ban campaign enjoyed, followed the elite debate. ABM opponents also pressed peace activists to address the issue. Early in 1968, David Inglis, then senior physicist at Argonne National Laboratories, urged SANE to oppose the ABM (Katz 1986: 129). Unable to achieve their goals through conventional politics, institutionallyoriented scientists turned to mass politics, trying to spur dissident activism in service of policy goals they had already defined.

Upon his election, President Nixon proposed accelerated ABM development to defend both US weapons and major metropolitan areas, essentially ignoring ABM opponents. This engendered a wave of activism among both atomic scientists who doubted the wisdom and feasibility of such systems, and local residents who opposed deployment of nuclear weapons near their homes. Activists sponsored teach-ins and rallies in cities where ABMs were 
to be deployed, including Chicago, Seattle, and Boston. This alliance, between elite opposition and mass action, created a strong political force. Coordinated by groups like the new Union of Concern Scientists, formed to organize scientific opposition to the war in Vietnam, ABM opponents testified before Congress, giving cover to congressional opponents, and conducted public education campaigns to buttress opposition at the grassroots. In August 1969, the Senate was deadlocked on the ABM, and the 1970 appropriation was saved only by Vice President Agnew's tie-breaking vote.

Nixon's staff was surprised that the strongest opposition came from cities due to be "protected" by ABMS-they'd expected protests from cities left "undefended." Better understanding the political risks attending the ABM, Nixon worked to develop an institutional accomodation of the opponents' concerns. He redefined the ABM's mission to defend weapons rather than cities, relocating potential sites from metropolitan areas to remote missile fields in less politically risky locales like Grand Forks, North Dakota. In doing so he separated expert elite opposition from its grassroots activist base. Nixon also began negotiations to limit ABM systems as a precursor to the 1972 SALT treaty.

The ABM never dominated the political debate, as nuclear weapons issues were overshadowed by more immediately salient problems, particularly the Vietnam war and unrest in American cities. Nixon's clever political response to ABM opponents, compromise and active negotiations, made it difficult for activists to build a broad movement. The eventual treaties effectively managed the size of an ABM effort, defusing public opposition in the process. Although ignoring potentially more destabilizing weapons, especially multiple warhead missiles (MIRVs), the ABM and SALT treaties continued the institutional arms control process and kept the public profile of nuclear weapons relatively low.

\section{The Nuclear Frezze Movement ${ }^{6}$}

After the end of the Vietnam war, peace activists had a difficult time generating any kind of national campaign. Presidents Nixon, Ford, and Carter all modernized US nuclear forces, but also worked to negotiate arms control measures with the Soviet Union. All could claim they were doing everything possible to limit nuclear armaments and the possibility of nuclear war, as military spending declined from the Vietnam era peak of 1968. Essentially, they were able to prevent the emergence of a single large policy problem to serve as focus for a large opposition movement. Activists did, however, stage

6 This section draws on Marullo 1991; Meyer 1990; Meyer and Kleidman 1991; Solo 1988; Waller 1987. 
를 Figure 4

New York Times Coverage of Opposition to US National Security Policies, BY MONTH, 1977-89

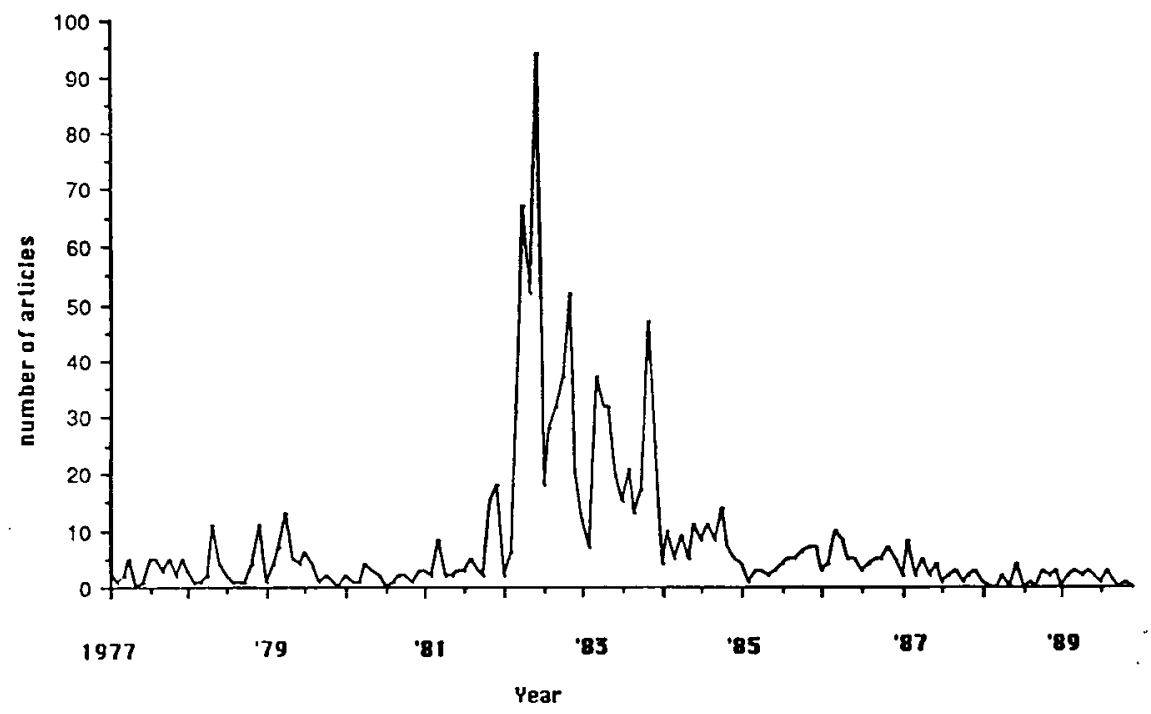

Source: New York Times Indes

smaller campaigns against particular weapons systems, most notably the B-1 bomber and the MX missile. In such efforts, however, they often played a subordinate role to elite allies, particularly the president. In the case of the B-1, for example, antinuclear activists found themselves lobbying members of Congress to support development of a nuclear-armed air launched cruise missile (ALCM) as an altemative (Kotz 1988: 154).

By the end of his term, Carter visibly retreated from his announced inaugural goal of eliminating nuclear weapons altogether, initiating a military build-up. Partly a response to world events, including the Soviet invasion of Afghanistan, the Nicaraguan revolution, and Iranian militants' taking American hostages in Teheran, Carter was also responding to increased domestic political pressure, particularly the successful organizing campaign of SALT II opponents. Activists who brought a "nuclear freeze" proposal to the Democratic national convention in New York City were rebuffed by the camps of both Carter and challenger Edward Kennedy. Both candidates likely saw a freeze platform plank as unwanted baggage for the general election. The 1980 electoral campaign preempted the development of strong opposition-for arms control advocates, Carter was still preferable to his Republican opponent. The freeze remained a solution in search of an opportunity: broad public concern with a national security policy problem. 
Ronald Reagan's election in 1980, and his explicit commitment to "rebuild" what he saw as America's neglected armed forces, emphasized that institutional routes for influence were not open to activists, and underscored activist concern with nuclear weapons policy generally. The new Reagan administration repeatedly and forcefully demonstrated its commitment to policies peace activists saw as bellicose. Administration officials were also candid in their assessments of the prospects of limited nuclear wars, the necessity of strategic superiority, and the futility of arms control; their rhetoric was untempered by qualifiers or guarded language about "options." Instead, they spoke cavalierly about fighting and winning nuclear wars (Scheer 1982), and worked to provide the weapons to do so.

At the same time, the administration purged from the State and Defense departments more moderate scientists and strategists unconvinced of the possibility or desirability of a war-winning strategic posture. In doing so, he forced into public a longstanding elite schism that was generally confined to expert venues. Many of these experts, robbed of access in the administration, sought a broader public audience. Roger Molander, for example, who had served on the National Security Council staff under Presidents Carter, Ford, and Nixon, formed a nonpartisan organization, Ground Zero, dedicated to public education on nuclear weapons. Mass media attention followed elite criticism of the Reagan program, subjecting the President's policies and advisers to an unusual degree of scrutiny. Finding doors for institutional access closed, activists directed their efforts elsewhere, creating a wave of transnational dissident activism.

Activists in the United States and Western Europe challenged the Reagan program. Antinuclear movements in Western Europe emerged strongly in 1981 , focusing specifically on stopping the NATO plan to deploy intermediate range nuclear missiles in five European countries (Risse-Kappen 1988; Rochon 1988). European activists appealed to their counterparts in the United States for help. Pacifists began direct action campaigns at military contractors, submarine bases, missile sites, and even the Pentagon. At the same time arms control advocates held educational events, sponsored symposia and teachins, pressed local governments to adopt resolutions opposing the Reagan program, and organized referenda campaigns

Although activists espoused a broad variety of ultimate goals and means, mass media grouped virtually all opponents of the Reagan administration's security policies under the banner of the "nuclear freeze." As articulated by Randall Forsberg (1984), a freeze proposal was the first step in a complicated and comprehensive program to remake world politics. As generally explained in mass media, it was an unfocused cry for arms control. The broad movement coalition made this framing struggle particularly important, and activist 
efforts to control it especially difficult. As the movement grew, staging a June 1982 rally in New York City attended by some one million people, activists were increasingly divided on the meaning of the proposal so many supported. Elite responses legitimated criticism of the Reagan administration, but redefined the activists' preferred policy solution.

Freeze activism, however vaguely defined, continued and brought increased public and government attention to nuclear weapons issues. Early in 1982, flanked by campaign leaders, Senator Kennedy announced that he would introduce a freeze resolution in Congress. When the resolution failed by one vote in the House of Representatives in 1982, activists pressed the issue in congressional campaigns the following fall, claiming credit for Democratic gains of 26 seats in the House. The following year, the Reagan administration actively sought to limit its political vulnerability on national security, softening its rhetoric and floating a series of arms control proposals. The House overwhelmingly passed an amended freeze resolution in 1983, although the resolution failed in the Senate.

As the movement made inroads in institutional politics the freeze coalition began to fray (Meyer 1993b). Institutionally oriented arms control groups cultivated Washington connections and tried to influence a variety of budget issues, urging Congress to push the President on arms control. This approach seemed a more direct route to political influence than public education or mass demonstrations, but the scope of the policy debate narrowed. At the same time, many pacifist and left-liberal groups continued their activities, but shifted to more salient issues, such as supporting economic sanctions against South Africa or preventing U.S. military intervention in Nicaragua. Finally, a number of peace groups were fully engaged in the upcoming election. Six of seven Democratic presidential hopefuls endorsed some version of a nuclear freeze proposal, including the eventual nominee, Walter Mondale.

The Reagan administration worked to ensure the election was not a referendum on either the freeze or its own national security policies, by offering a kind of institutional accommodation. In January of 1984, Reagan announced his new commitment to arms control negotiations, and to restoring summit meetings with the Soviet Union, offering conciliatory rhetoric to both freeze supporters and the Soviets. Paradoxically, Reagan's Strategic Defense Initiative, announced in 1983, allowed the President to shift the terms of debate, attacking freeze supporters for defending the status quo, and promising eventual deep reductions in nuclear arsenals and a benign end to mutual nuclear deterrence. At the same time, a somewhat strengthened congressional opposition prevented the most aggressive aspects of the Reagan build-up, limiting growth of the budget, and effectively mandating arms control (Fascell 1987). 
The nuclear freeze movement did not end the arm race, as its initiators explicitly intended, much less achieve the more ambitious goal of remaking US foreign policy. Nonetheless, it effectively rescued the previous bipartisan policy consensus, restricting the Reagan administration's initiatives. It retumed legitimacy and institutional access to advocates of arms control and nuclear restraint. Reagan's arms control proposals, offered more for domestic political reasons than international response, had extensive unexpected effects. The new posture offered incoming Soviet General Secretary Gorbachev a lever with which to reopen detente. When Gorbachev accepted the disproportionate cuts in nuclear forces Reagan had proposed, the administration was cornered. It couldn't reject its own proposals. This forced flexibility on arms control proved to be critical in ending the cold war (Meyer 1993a; RisseKappen 1991). The movement won far less than it intended, yet it turned out to be far more significant than anyone involved would have guessed.

\section{Conclusions}

Explanations of protest cycles that emphasize constant causes, such as human disappointment or intractable social problems, clearly miss something important. Collective behavior explanations would suggest that waves of activism would reflect aggregate psychological phenomena, in the case of nuclear weapons, fear. As noted above, however, public opinion on nuclear weapons has remained generally constant. Only when elite actors have legitimated criticism of government policy have strong movements emerged, and then through organized political efforts, not anomic spontaneous action. A narrow resource mobilization view, which emphasizes the provision of resources and the constancy of grievances, neglects that resources become available when policy changes and the intensity and focus of grievances changes.

Clearly, protest cycles are related to the broader political context and the policymaking process. The cases suggest that policy shifts can provide political space for challenging movements, and that governments may alter their policies in order to reclaim that political space. Elite actors, particularly scientists and strategic experts, mediate between the state and protest movements, identifying which aspects of policy are most vulnerable to assault, legitimating and sometimes aiding insurgent movements, and framing solutions to the political problems movements cause. As government reaches an accomodation with elite opponents, it becomes progressively harder for dissidents to convince supporters of the need or efficacy of extra-institutional protest.

It is also clear that public policy and political alignments are critical and fluid aspects of the structure of political opportunity that determine the political space available to dissidents. In two of the four cases presented here, the 
scientists' campaign for international control, and the anti-ABM campaign, dissent was largely confined to elite debate and action, as mass attention focused on more proximate or urgent issues. In the scientists' campaign, public attention after World War II focused first on domestic issues; when international concerns re-emerged, the Soviet threat overshadowed public fears of nuclear weapons. Proponents of world government or international control of nuclear weapons did not frame their differences with government policy with sufficient clarity to mobilize mass action. Similarly, during the ABM debate public attention generally focused on other more salient issues, particularly the Vietnam war; grasssroots activism was confined to areas scheduled to host ABM systems. President Nixon split the grassroots from their elite supporters by changing the ABM's mission and deployment sites. He also robbed $\mathrm{ABM}$ opponents of their political initiative by actively pursuing arms control agreements.

The apparent policy problems were larger and more immediate for the two mass movements, the test ban and the nuclear freeze. Political and military leaders in both the middle 1950s and early 1980s openly spoke of fighting and winning nuclear wars. Eisenhower, Kennedy, and Reagan all stepped up civil defense plans, bringing the conduct of US nuclear policy home to many Americans. In both cases dissident elites who had lost institutional political battles sought to mobilize mass support for their positions. Public debates focused on the simplest and most salient aspects of policy: atmospheric testing in the 1950s and 1960s; the propensity of the Reagan administration to wage a nuclear war in the 1980s. With these narrow focal points, broad movements grew very quickly. At the same time, however, Presidents could split the dissident coalitions by addressing only the most egregious irnitant. The Kennedy administration ended superpower atmospheric testing; the Reagan administration learned the civilities of arms control and conciliatory rhetoric.

Movements subsided when an administration institutionalized at least part of its opposition, narrowing the public debate and defusing public concerns and activism. This institutional accomodation entailed symbolic concessions, and sometimes real changes in policy. President Truman visibly pursued international control of nuclear weapons, albeit in a way that made success extremely unlikely. President Eisenhower made bureaucratic changes to strengthen the institutional position of arms control advocates, first appointing a disarmament advisor, then creating a special scientific advisory board. Secretary Dulles argued for establishing an arms control process, primarily to manage domestic opposition, not the Soviet Union. The Kennedy administration actively sought a test ban, and used the popular movement to negotiate with both the Soviet Union and the US military. President Nixon's flexibility 
on deploying and negotiating about the $\mathrm{ABM}$, reflected, if not the pressure of anti-ABM forces, at least the wisdom of their arguments. The nuclear freeze movement forced the Reagan administration to revise its public posture for domestic political reasons. The administration made rhetorical concessions on arms control to its opponents in the United States and West Europe, openings Gorbachev used to resurrect detente.

By examining the fluidity of political opportunity on one set of issues over time, I have shown the need to look at both stable and dynamic aspects of opportunity-structure and space- to understand protest cycles. Protest movements emerge when institutionally oriented actors lose faith in the efficacy of institutional politics. At such times, they may forge alliances with activists making broader claims and engaging in extra-institutional action. The resultant movements lodge broad claims against the state, but generally disperse after an administration re-integrates dissident elite into institutional politics, often by restoring previous policies. The cyclic nature of movement challenges reflects the shifting attention of elite actors from institutional venues to extra-institutional ones. Movements may then have the odd effect of preserving policies they find abhorrent. Whether peace activists can mobilize challenges after the Cold War, during a period of military demobilization when all policy positions are subject to debate and intense scrutiny, is a critically important-and open-question.

\section{REFERENCES}

Amenta, Edwin, and Yvonne Zylan. 1991. "It Happened Here: Political Opportunity, the New Institutionalism, and the Townsend Movement." American Sociological Review. 56: 250-65.

Bacharach, Peter, and Morton S. Baratz. 1970 Power and Poverty. New York: Oxford University Press

Berry, Jeffrey M. 1977. Lobbying in the Public Interest. Princeton, NJ: Princeton University Press.

Bigelow, Albert. 1959. The Voyage of the Golden Rule. Garden City, NY: Doubleday.

Boyer, Paul. 1985. By the Bomb's Early Light: American Thought and Culture at the Dawn of the Nuclear Age. New York: Pantheon.

Brand, Karl-Werner. 1990. "Cyclical Aspects of New Social Movements: Waves of Cultural Criticism and Mobilization Cycles of New Middle-class Radicalism." In Russell Dalton and Manfred Kuechler, eds, Challenging the Political Order. pp. 23-42. New York: Oxford University.

Bundy, McGeorge. 1988. Danger and Survival: Choices about the Bomb in the First Fifty Years. New York: Random House.

Byrne, Paul. 1991. "CND: The Second Phase." International Social Movement Research. 3: 67-90.

Caldicott, Helen. 1984. Missile Envy: The Arms Race and Nuclear War. New York: William Morrow. 
Cannon, Lou. 1991. President Reagan: The Role of a Lifetime. New York: Simon and Schuster.

Chatfield, Charles, and Peter Van den Dungen, eds. 1988. Peace Movements and Political Cultures. Knoxville: University of Tennessee Press.

Cousins, Norman. 1945. "Modern Man is Obsolete." Saturday Review. 28 (no. 33, August 18): 5-9.

Dahl, Robert A. 1963. Who Governs? New Haven: Yale University Press.

DeBenedetti, Charles. 1980. The Peace Reform in American History. Bloomington: Indiana University Press.

- ed. 1986. Peace Heroes in Twentieth Century America. Bloomington: Indiana University Press.

Divine, Robert A. 1978. Blowing on the Wind: the Nuclear Test Ban Debate, 1954-1960. New York: Oxford University Press.

Downs, Anthony. 1957. An Economic Theory of Democracy. New York: Harper \& Row. - 1972. "Up and Down with Ecology: The 'Issue-Attention Cycle'." The Public Interest 28 (Summer): 38-50.

Edelman, Murray. 1971. Politics as Symbolic Action. Chicago: Markham.

Eisinger, Peter K. 1973. "The Conditions of Protest Behavior in American Cities." American Political Science Review 67: 11-28.

Ellsberg, Robert, ed. 1983. By Little and By Little: Selected Writing of Dorothy Day. New York: Knopf.

Fascell, Dante. 1987. "Congress and Arms Control." Foreign Affairs 65 (Spring): 730-49.

Forsberg, Randall. 1984. "The Freeze and Beyond: Confining the Military to Defense as a Route to Disarmament." World Policy Journal 1 (Winter): 287-318.

Freeman, Jo. 1975. The Politics of Women's Liberation. New York: David McKay.

Gamson, William A. 1988. "Political Discourse and Collective Action." International Social Movement Research 1: 219-44.

- 1990. 2nd ed. The Strategy of Social Protest. Belmont, CA: Wadsworth.

Goldstone, Jack A. 1980. "The Weakness of Organization: A New Look at Gamson's The Strategy of Social Protest." American Joumal of Sociology 85: $1017-42$.

Graham, Thomas W. 1989. American Public Opinion on NATO, Extended Deterrence, and Use of Nuclear Weapons. Cambridge, MA: Harvard University Center for Science and International Affairs.

Hansen, John Mark. 1985. "The Political Economy of Interest Group Membership." American Political Science Review 79: 79-96.

Herken, Gregg. 1987. Counsels of War. New York: Oxford University Press.

Hirschman, Albert O. 1970. Exit, Voice, and Loyalty. Cambridge: Harvard University Press.

- 1982. Shifting Involvements. Princeton, NJ: Princeton University Press.

Huntington, Samuel P. 1961. The Common Defense: Strategic Programs in National Politics. New York: Columbia University Press.

Jenkins, J. Craig, and Charles Perrow. 1977. "Insurgency of the Powerless: Farm Worker Movements (1946-1972)." American Sociological Review 42: 249-68. 
Josephson, Harold. 1988. "The Search for Lasting Peace: Internationalism and American Foreign Policy, 1920-1950." In Chatfield and Van den Dungen, Peace Movements and Political Cultures, pp. 204-21 Knoxville: University of Tennessee Press.

Katz, Milton S. 1986. A History of SANE, 1957-1985. New York: Greenwood. Katz, Nick. 1988. Wild Blue Yonder: Money, Politics, and the B-1 Bomber. New York: Pantheon.

Kelley, Kitty. 1991. Nancy Reagan: The Unauthorized Biography. New York: Simon and Schuster.

Kingdon, John. 1984. Agendas, Alternatives, and Public Policies. Boston: Little, Brown.

Kitschelt, Herbert P. 1986. "Political Opportunity Structures and Political Protest: Anti-Nuclear Movements in Four Democracies." British Journal of Political Science 16: 57-85.

Klandermans, Bert. 1991. "The Peace Movement and Social Movement Theory." International Social Movement Research 3: 1-39.

Kleidman, Robert. 1993 (forthcoming). Organizing for Peace: Neutrality, the Test Ban, and the Freeze. Syracuse, NY: Syracuse University Press.

Knopf, Jeffrey W. 1991 "Domestic Politics, Citizen Activism, and US Nuclear Arms Control Policy." Doctoral dissertation, Stanford University.

Kornhauser, William. 1959. The Politics of Mass Society. Glencoe, IL: Free Press. Lipsky, Michael. 1970. Protest in City Politics. Chicago: Rand-McNally.

Marullo, Sam. 1991. "US Grassroots Opposition to the Euromissile Deployment." International Social Movement Research 3: 283-310.

McAdam, Doug. 1982. Political Process and the Development of Black Insurgency. Chicago: University of Chicago Press.

McCarthy, John D., and Mayer N. Zald. 1977. "Resource Mobilization and Social Movements: A Partial Theory." American Journal of Sociology 82: 1212-41.

McCrae, Frances B., and Gerald E. Markle. 1989. Minutes to Midnight: Nuclear Weapons Protest in America. Newbury Park, CA: Sage.

McFarland, Andrew. 1984. Common Cause: Lobbying in the Public Interest. Chatham, NJ: Chatham House.

McNamara, Robert S. 1968. The Essence of Security: Reflections in Office. New York: Harper \& Row.

Meyer, David S. 1990. A Winter of Discontent: The Nuclear Freeze and American Politics. New York: Praeger.

. 1993a. "Below, Beyond, Beside the State: Peace and Human Rights Movements and the End of the Cold War." In David Skidmore and Valerie Hudson, eds., The Limits of State Autonomy: Societal Groups and Foreign Policy. Boulder, CO: Westview.

. 1993b. "Institutionalizing Dissent: The United States Political Opportunity Structure and the End of the Nuclear Freeze Movement." Sociological Forum 8 (June): 2: 157-79.

Meyer, David S., and Douglas R. Imig. 1993. "Political Opportunity and the Rise and Decline of Interest Group Sectors." Social Science Joumal 30 (July): 3: 253-70. 
Meyer, David S., and Rob Kleidman. 1991. "The Nuclear Freeze Movement in the United States." International Social Movement Research 3: 231-61.

Miller, Steven E. 1985. "The Viability of Nuclear Arms Control: US Domestic and Bilateral Factors." Bulletin of Peace Proposals 16 (June): 263-76.

Mushaben, Joyce M. 1985. "Cycles of Peace Protest in West Germany: Experience from Three Decades." West European Politics 8 (January): 24-40.

Oberschall, Anthony. 1973. Social Conflict and Social Movements. Englewood Cliffs, NJ: Prentice-Hall.

Olson, Mancur Jr. 1965. The Logic of Collective Action. Cambridge, MA: Harvard University Press.

Piven, Frances Fox, and Richard A. Cloward. 1979. Poor People's Movements. New York: Vintage.

Primack, Joel, and Frank von Hippel. 1974. Advice and Dissent. New York: Basic Books.

Reagan, Ronald W. 1990. An American Life: The Autobiography. New York: Simon and Schuster.

Risse-Kappen, Thomas. 1988. The Zero Option: INF, West Germany, and Arms Control. Boulder, CO: Westview.

- 1991. "Public Opinion, Domestic Structure, and Foreign Policy in Liberal Democracies." World Politics 43 (no. 4, July): 479-512.

Robinson, Jo Ann. 1986. "A. J. Muste: Prophet in the Wilderness of the Modern World." In Charles DeBenedetti, Peace Heroes in American History, pp. 147-67. Bloomington: Indiana University Press.

Rochon, Thomas R. 1988. Mobilizing for Peace: The Antinuclear Movements in Western Europe. Princeton, NJ: Princeton University Press.

Ryan, Charlotte. 1991. Primetime Activism. Boston: South End Press.

Salisbury, Robert H. 1969. "An Exchange Theory of Interest Groups." Midwest Journal of Political Science 13: 1-32.

Schattschneider, E. E. 1960. The Semi-Sovereign People. New York: Holt, Reinhart and Winston.

Scheer, Robert. 1982. With Enough Shovels: Reagan, Bush Nuclear War. New York: Vintage.

Schlesinger, Arthur. 1986. Cycles of American History. Boston: HoughtonMiflin.

Seaborg, Glenn T. 1981. Kennedy, Khrushchev and the Test Ban (with Benjamin S. Loeb). Berkeley: University of California Press.

Schlozman, Kay Lehman, and John T. Tiemey. 1986. Organized Interests and American Democracy. New York: Harper and Row.

Smelser, Neil. 1963. Theory of Collective Behavior. New York: Free Press.

Smith, Alice Kimball. 1965. A Peril and a Hope: The Scientists' Movement in America: 1945-47. Chicago: University of Chicago Press.

Solo, Pam. 1988. From Protest to Policy: Beyond the Freeze to Common Security. Cambridge, MA: Ballinger.

Solop, Fred. 1991. "Agenda Setting-Agenda Erosion: The Ebb and Flow of Policy Process." Presented at the annual meeting of the American Political Science Association. September, Washington, DC. 
Tarrow, Sidney. 1988. "National Politics and Collective Action." Annual Review of Sociology 14: 421-40.

- 1989. Struggle, Politics, and Reform: Collective Action, Social Movements, and Cycles of Protest. Ithaca, NY: Center for International Studies, Cornell University, Occasional Paper No. 21.

- 1991. "Aiming at a Moving Target': Social Science and the Recent Rebellions in Eastern Europe." PS 24 (March): 12-20.

Tilly, Charles. 1978. From Mobilization to Revolution. Reading, MA: Addison-Wesley.

Truman, David. 1951. The Governmental Process. New York: Knopf.

Walker, Jack L. 1983. "The Origin and Maintenance of Interest Groups in America." American Political Science Review 72: 390-406.

1991. Mobilizing Interest Groups in America: Patrons, Professions, and Social Movements. Ann Arbor, MI: University of Michigan Press.

Waller, Douglas C. 1987. Congress and the Nuclear Freeze: An Inside Look at the Politics of a Mass Movement. Amherst: University of Massachusetts Press.

Wittner, Lawrence S. 1984. Rebels Against War: The American Peace Movement, 1933-83. Philadelphia, PA: Temple University Press.

1988. "The Transnational Movement Against Nuclear Weapons, 1945-1986: a Preliminary Survey." In Chatfield and Van den Dungen, Peace Movements and Political Cultures, pp. 265-94. Knoxville: University of Tennessee Press.

Yankelovich, Daniel, and John Doble. 1984. "The Public Mood: Nuclear Weapons and the USSR." Foreign Affairs 63: 33-46.

York, Herbert P. 1987. Making Weapons, Talking Peace: A Physicist's Odyssey from Hiroshima to Geneva. New York: Basic Books.

Received: February 2, 1992

Accepted for Publication: January 6, 1993 